\title{
МОНГОЛ ТУУЛЬ ДАХЬ ЕРОТИК ДҮРСЛЭЛ
}

\author{
X.Kamyy \\ ШУА-ийн Хэл зохиольн хүрээлэн, Аман зохиол судлалын сектор \\ Цахим иуудан: katuи_balchig@yahoo.com
}

Монгол тууль нь хэдэн зууны тэртээгээс билиг танхай туульчдын оюуны цэцээр шүүгдэн тунгаагдсан монголчуудын ахуй амьдрал, хэл, соёл, түүх, шашин шүтлэг, зан үйл, ертөнцийг үзэх үзэл, хүсэл мөрөөдлийг тусгасан үгийн урлагийн сонгодог туурвил учраас хэл утга зохиол, түүх, соёл, зан үйл, архелоги, угсаатны судлалд үнэлж баршгүй эх хэрэглэгдэхүүн болсоор ирсэн бөгөөд хойшид ч болох нь гарцаагүй билээ. Үнэндээ монгол туульсыг унших дутам монгол угсаатны нийгэм, түүх, ахуй, утга соёлын байдал нүдэнд харагдаж, чихэнд сонсогдож, гарт тэмтрэгдэх шиг болдог юм.

Хүний амьдрал баялаг олон талтай гэдгийг хэн хүнгүй мэднэ. Ухаант хүн гэдэг нэгэн төрлийн амьтан энэ хорвоод ирсэн өдрөөсөө эхлээд, буцах хүртлээ элдвийг Үзэн туулж, баярлан жаргаж, гуниглан зовохдоо өөрийнхөө амьдралын нэг хэсэг мөчлөгийг хүмүүсийн нүдний дор ил тод явуулдаг бол зарим хэсгийг нь далд нууцлаг байдлаар өнгөрөөдөг байна. Энэ бол хүнийг адгуусаас ялгах гол шинж ч гэж үзэж болно. Гэхдээ хүмүүний амьдралын тэрхүү далд нууцлаг зүйлийг ор тас нууж, хав дараад байдаггүй байжээ. Ард түмэн өөрсдийнхөө гэгээн оюун, тунгалаг мэлмий, торгон мэдрэмжээрээ таньж мэдсэн шалиг (еротик) зүйлийг монгол туульд хэрхэн дүрслэлийг ажиглаж үзэхийг хичээлээ.

“Жангар” туулийн Алтан цээж, Жангар хоёрын байлдсан бүлэгт: Бөх

мөнгөн шигшрэг Жангарыг олзолж ирээд, Шилтэй зандан гэрэл хатандаа энэ хүвгүүнийг талхалж чавчаад, тахиа, нохой хоёрт идүүл? гээд мордоод явав. Ард нь Хонгор Шилтэй зандан гэрэл хатан ээж нь Жангарыг алах гэхэд үүнийг албал намайг бас ал хэмээгээд дээр нь хэвтэж алуулахгүйгээр барахгүй:

“Ээжээ! Үүний далд нь орсон сумыг гаргаж өгөгтүн!

Ариун шагшаавадтай* [Сүхбаатар.1997.218] эм ээж таныг

Гурав алхахаар гарна" гээд байхлаар нь

Хүвгүүнийхээ сэтгэлийг бодоод

Хоёр алхаад гуравдах дээр нь

Шархын аман дээр гарч ирчихээд

Уналгүй байгаад байв

“Ээжээ! Энэ яагаад ингэв?” гэж

Араг улаан Хонгорыг асуусанд

“Харьд ирсний хойт жилд

Хаврын эмнэг гүүдээ саахаар яваад

Азрага гүүнд гарсныг тачааж харснаас болж

Гаралгүй байдаг биз” гээд

Гараа наманчлан сөгдөөд суухад нь

Сум нь унаад одов [Дүгэрсүрэн.1963.20] гэж гардаг.

Энэ дүрслэлд Хонгор Жангартай азаргыг хараад дур тачаал нь хүрснээс болж нөхөрлөхөөр ирсний дараа жилийн хавар далд нь орсон сум гүйцэд мултрахгүй байна гүҮ саахаар явж байгаад, гүҮ хурааж байгаа хэмээн тайлбарлаж байна. 
Монголчууд эрт дээр үеэс адгуус мал, амьтны ороо орсон үеийн үйлдлийг харж зогсохыг ёс бус зүйл хэмээн үзэж хүүхэд залуучуудад аль болохоор харуулахгүй байхыг хичээдэг байжээ. Энэ зан үйл одоо ч гэсэн хөдөө орон нутагт уламжлагдсан хэвээр байна. Тиймээс Жангарын туульд ариун шагшаабадтай Хонгорын ээж нь Жангарын гаж буруу үйлийг цээрлэн наминчилж тэрхүҮ зүй бус шалиг санааг нь ариулснаар сум нь мултарч байгааг ийм байдлаар дүрсэлсэн байна.

Жангарын туульд гардаг нэгэн өвөрмөц дүрийн нэг бол Жангарын эрхэм сөнч Эрх тугийн хөвгүүн Орчлонгийн Сайхан Минъяан бөгөөд түүний үзэсгэлэнт төгөлдөр гоо сайхан зүс царайг Кинисын бүлэгт:

Орох урвал шар нарны өнгөтэй

Гарах шар нарны дүртэй

Гэгээн дунд нь үйл барим сайхан

Гэргий хүн үздэг болохной нь

Гэр, малаа гээж орхиод

Гэнэн (гаслан Б.К) хойноос нь дагадаг

Хүүхэн үзэхнэй нь

Хөхний гурван товч

Заяандаа (аяндаа Б.К) мултардаг (Жанһьр I боть. 1978.241)

гэж хүмүүсийн хүсэл тачаалыг хөдөлгөх орчин үеийн тайчих еротик урлагийг санагдуулам гайхалтай дүрсэлсэн байдаг.

Хэрвээ ХХ зууны 20-90-аад оны үе буюу нэг намын үзэл суртал ноёрхсон социализмкомунизмын бүтээн байгуулалтын үед ийм зүйл бичиж хэвлүүлсэн бол тэр дорхноо хөрөнгөтний үзэл суртал сурталчиллаа хэмээн ангийн дайсан болж дээлээ нөмрөх нь энүүхэнд байлаа. Ер нь тэгээд Жангар туульд монгол үндэстний ахуй амьдрал, зан үйл, үзэл бодол, итгэл бишрэл, хүсэл мөрөөдөл зэрэг ахуй, ухамсрын олон талыг тусгасан байдаг учраас өргөн олон уншигчид хийгээд эрдэмтэн судлаачдын анхаарлыг татсаар иржээ.

Ийм зүйл зөвхөн “Жангар” туульд биш бусад туульд ч байна. Тухайлбал “Даньхүрэл” туульд Даньхүрэл баатар би энэ насандаа нэг сайн унтаж амарч чадсангүй, арван таван хоног сайхан унтаад авъя. Заан буйдан чи найман байр хүрэл хонгор адууг сайн хариулж бай гээд:

Дунгийн цагаан бааванхайд ороод

Хармалжин чимэгт

Орон дээр гарч

Хар торгон түнтгээ дэрлээд

Хатан Төгрөг гэрэлээ

Өвөрлөж аваад унтав аа [Катуу.2006.344]

гэж нэг бус удаа гардаг. Монгол туульд үнэндээ бэлгийн харилцааны асуудлыг тухайн үед үүнээс илүүгээр дүрслэн үзүүлэх боломж мэдээж байхгүй байсан байхаа.
Мөн түүнчлэн урианхайн нэрт туульч С.Чойсүрэнгийн хайлсан "Наран хаан хүҮ" туульд:

Доод замба тивийн

Довон хар бөх аавтай

Дээд хаан хурмастын

Зүүдэн солонго дагина ээжтэй 
Навч нарийхан цавдартай

Арын өнчин яргай чи бол

Дээд хаан хурмастын

Зүүдэн солонго дагина

Дунд замба тивд орж ирээд

Наран хаан хүүгийн

Нарийхан гүрмэл хар

Уулын алтан агуйд

Нямба цамба бүтээж байхад

Доод замба тивийн

Довон хар бөх

ЗүҮдэн солонго дагинатай

Алтан агуйд уулзан танилцаж

Хүсэл жаргалаа хангаж зүүдэллээ

Зүүдэн солонго дагиныг

Зүүдэлж хоносон шөнө

Чи заяаж төрсөн учиртай билээ гэх буюу

Зүүдэн солонго дагинын

Дээд хаан хурмаст аав

Дунд замба тивд ирүүлж

Нямба цамба бүтээлгэе чинь

Эр эмийн ажил бүтээж явж гээд

Цаазаар ална гэж заагаад

Алтан агуйн аманд

Долоон их эхтэй

Догшин хар харзын эхэнд

Хаяад явсан учиртай билээ [Катуу.2010.403-404]

гэж гардаг. Энд Дээд хурмастын хаан Зүүдэн солонго охиноо дунд замба тивд Бурханы шашны ном уншуулахаар явуулсан чинь Доод замба тивийн Довон хар бөх Дээд хурмастын Зүүдэн солонготой хүсэл жаргалаа хангаж байна хэмээн зүүдэлсэн төдийгөөр Дээд хурмастын хаан охиноо эр эмийн ажил хийж явлаа хэмээн хардаад Доод замба тивд хаяад явж байна. Ийнхүу энэ туульд бэлгийн харилцааг зүүдээр эерүүлэн дүрсэлсэн байдаг.

Харин С.Чойсүрэнгийн хайлсан “Талын хар бодон” туульд Тэвэг алтан зул Талын хар бодоныг ирж явааг мэдээд:

Талын хар бодоны

Тас хар хээр морин

Азарганы дусаалаас дусаад

ГүҮний умайгаас л унасан

Гүүний хөвүүн болохоор

Миний Тэл хонгор мөн адил гэгийт

Талын хар бодон

Эр хүний дусаалаас дусаад

Эхийн умайгаас унасан

Күмний хөвүүн болохоор

бол “Эзэн улаан бодон” туульд:

Тэвэг алтан зул мөн адилхан гэгийт [Катуу.2010.466] гэж хэлдэг 
Ямар ажиргын тусаалаас тусаж

Ямар гүүний умайнаас унаксан

Морин ийм сайхан өндөр бүдүүн

Эмнэг тарган болдов! гэж гайхалцаад

Ямар эр күмүүний дуслаас дусаж

Ямар экийн умайнаас унаксан

Күмүүний күвүүн ийм сайхан эртэй туртай

Эрдүүн сайхан болдов! гэж сонирхоод

Халиагаад өнгөрүүлж байжээ (Катуу.2010.768).

Энд $\quad$ хүн, амьтан ялгаагүй $\quad$ эцгийн энгийн эротик дүрслэлээр дүрслэн өгүүлсэн цагаан дусаал, эхийн улаан дусаалаас үүсч, байна.

эхийн умайгаас унадаг зүй тогтлыг тун

Ашигласан бүтээлийн жагсаалт

1. Дүгэрсүрэн Т. Жангар. УБ., 1963

2. Жанһьр хальмьг баатьрльг дуулвьр /25 бүлгийн текст/ I боть, Москва., 1978

3. Катуу Б. Алдарт туульч М.Парчины туульс. УБ.,2006

4. Катуу Б. Нэрт туульч С. Чойсүрэнгийн туульс. УБ.,2010

5. Сүхбаатар О. Монгол хэлний харь үгийн толь. УБ.,1997 *Шагшаабад: caм. siksapada; мо.б. sagsabad; “суртлын шүтээн”; Гаж буруу үйлсийг иээрлэж, сэтэлийг боож барих санаа, сахилга; сэтгэлийн үндсэнд сэрүүнийг олгуулагч гэсэн утгатай. Нисваанисын халуун энэлгийг амарлуулаад сэрҮҮн болсны нэр ч гэдэг. Тодруулбал, энэлгийг сайтар арилгах, хамаг өвчнийг амирлуулах, тэнгэр хүмүүний насыг ияаламгүй болгох, ямагт бусдын тусад орох тэргүүтнийг сахих сахилга; "шагшаа” нь ухаан буюу мэдлийг аваад суралиах, "бад” нь шүтээн буюу оюуны нэр 